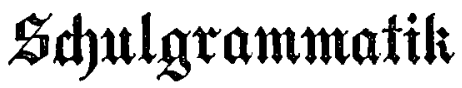

ber

\section{Eateinifuch Spand}

Zumädyft für Realfdunlen bentbeitet

volt

2. $\mathfrak{R} \mathfrak{t} \mathfrak{h} \mathfrak{r}$,

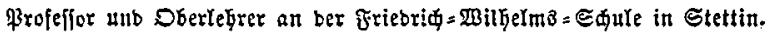

Swrite Zatplage.

Berlin, 1858.

Berlag bon Georg Reimer. 
